\title{
Pengaruh Posisi Dinding Geser Terhadap Kinerja Struktur Pada Gedung Tidak Beraturan Dengan Menggunakan Metode Response Spectrum
}

\author{
Arif Kurnia $^{1}$, Sri Hartati Dewi ${ }^{2}$, Mahadi Kurniawan ${ }^{3}$ \\ ${ }^{1}$ Program Studi Teknik Sipil, Universitas Islam Riau \\ ${ }^{2,3}$ Program Studi Teknik Sipil, Universitas Islam Riau \\ Jalan Kaharuddin Nasution No. 113 Perhentian Marpoyan Pekanbaru 28284
}

\begin{abstract}
Abstrak
Dinding geser adalah slab beton bertulang yang dipasang dalam posisi vertikal pada sisi gedung. Dinding geser merupakan salah satu sistem yang berfungsi menjaga kekakuan struktur, maka posisi dinding geser ditempatkan pada lokasi-lokasi tertentu, dengan itu penggunaan dinding geser dapat digunakan secara efektif dalam menahan beban yang diterimanya.

Pemodelan struktur gedung dilakukan dengan bantuan software ETABS. Analisis beban gempa menggunakan metode respons spektrum. Pemodelan struktur dibuat untuk gedung tanpa menggunakan dinding geser dan 3 model gedung menggunakan dinding geser dengan posisi yang berbeda. Penentuan posisi dinding geser dilakukan dengan cara uji coba sehingga didapat posisi yang paling efektif. Perhitungan beban gempa mengacu pada pedoman SNI 1726-2012, beban mati berpedoman pada PPURG-1987 dan untuk beban hidup berpedoman pada SNI 1727-2013.

Dari hasil perhitungan pada gedung tidak beraturan dengan metode respons spektrum didapat nilai untuk kinerja simpangan maksimum dari 4 model gedung. Simpangan maksimum arah sumbu x pada Gedung tanpa dinding geser sebesar 157,57 mm, pada gedung dengan dinding geser model 1 sebesar 123,41 mm, pada gedung dengan dinding geser model 2 sebesar 125,30 mm, pada gedung dengan dinding geser model 3 sebesar 94,46 mm. Simpangan maksimum arah sumbu y pada gedung tanpa dinding geser sebesar 193,13 mm, pada gedung dengan dinding geser model 1 sebesar 143,79 mm, pada gedung dengan dinding geser model 2 sebesar 141,16 mm, pada gedung dengan dinding geser model 3 sebesar 119,24 mm. Dari hasil kinerja simpangan maksimum pada Gedung tidak beraturan dengan metode respons spektrum didapat posisi dinding geser yang paling efektif adalah pada Gedung dengan dinding geser model 3
\end{abstract}

Kata Kunci : Dinding geser, respons spektrum, software ETABS, beban gempa, simpangan maksimum 


\section{PENDAHULUAN}

\section{Latar Belakang}

Kondisi geografis Indonesia yang terletak pada pertemuan empat lempeng tektonik utama yaitu Lempeng Eurasia, IndoAustralia, Pasifik, dan Filipina mengakibatkan seringnya terjadi gempa baik ringan, sedang, maupun tinggi yang akan mempengaruhi kinerja struktur gedung. Salah satu wilayah yang sering dilanda gempa adalah kota Bengkulu. Dikarenakan Bengkulu terletak pada dua lempeng tektonik yaitu lempeng IndoAustralia dan Eurasia.

Pembangunan struktur gedung bertingkat semakin banyak di bangun pada era saat ini. Akibatnya kebutuhan akan lahan yang luas semakin sulit diperoleh. Sehingga pembangunan gedung bertingkat akan berpengaruh pada bentuk bangunan yang cenderung tidak beraturan. Dalam pembangunan struktur gedung, semakin tinggi bangunan maka respon struktur terhadap beban lateral (akibat gempa dan angin) akan menjadi semakin penting. Dengan adanya beban lateral (akibat gempa dan angin) gedung akan mengalami simpangan horizontal akibat beban tersebut. Apabila simpangan horizontal melebihi syarat aman yang telah ditetapkan oleh SNI 1726-2012 maka gedung akan mengalami kegagalan. Salah satu solusi yang digunakan untuk meningkatkan kinerja struktur gedung bertingkat dalam mengatasi simpangan horizontal yang melebihi syarat aman adalah dengan menggunakan dinding geser.

Dinding geser adalah slab beton bertulang yang dipasang dalam posisi vertikal pada sisi gedung. Dinding geser salah satu sistem yang berfungsi menjaga kekakuan struktur, maka posisi dinding geser ditempatkan pada lokasi-lokasi tertentu, dengan itu penggunaan dinding geser dapat digunakan secara efektif untuk menahan beban yang diterimanya.

Terdapat beberapa metode yang bisa digunakan dalam menghitung terhadap beban gempa diantaranya adalah Analisis dengan metode respons spektrum, dimana metode respons spektrum salah satu metode yang diizinkan untuk menganalisis struktur gedung tidak beraturan.

Hal tersebut melatarbelakangi penulis akan mengkaji "Pengaruh Posisi Dinding Geser Terhadap Kinerja Struktur pada Gedung tidak Beraturan Dengan Menggunakan Metode Respons Spectrum".

\section{Tujuan Penelitian}

Adapun tujuan yang ingin dicapai dalam penelitian ini adalah sebagai berikut :

1. Untuk mengetahui kinerja simpangan antar lantai dari beberapa posisi dinding geser pada gedung tidak beraturan dengan metode respons berdasarkan SNI 1726:2012.

2. Untuk menentukan posisi dinding geser yang paling efektif pada gedung tidak beraturan dengan menggunakan metode respons spektrum.

\section{Landasan Teori}

Untuk gedung tinggi, diperlukan kekakuan yang cukup untuk menahan gayagaya lateral yang disebabkan oleh angin dan gempa. Jika bangunan tinggi tersebut tidak didesain secara benar terhadap gaya-gaya ini, dapat timbul tegangan yang sangat tinggi, serta getaran dan goyangan ke samping ketika gaya-gaya tersebut terjadi. Akibatnya tidak hanya menimbulkan kerusakan parah pada bangunan tersebut tetapi juga mengakibatkan ketidaknyamanan pada penghuni.

Ketika dinding beton bertulang dengan kekakuan bidang datar yang sangat besar ditempatkan pada lokasi-lokasi tertentu yang cocok dan strategis, dinding tersebut dapat digunakan secara ekonomis untuk menyediakan tahanan beban horizontal yang diperlukan. Dinding-dinding seperti ini disebut dinding geser dan pada dasarnya merupakan balok kantilever vertikal yang tinggi dan memberikan stabilitas lateral kepada struktur dengan menahan geser dan momen tekuk pada bidang datar yang disebabkan gaya-gaya lateral. 


\section{METODE PENELITIAN}

\subsection{Lokasi Penelitian}

Penelitian dilakukan dengan mengambil contoh dari gedung UIN Maliki Malang. Gedung direncanakan 8 lantai, tetapi gedung diasumsikan berada di kota Bengkulu.

\subsection{Jenis Penelitian}

Penelitian ini merupakan penelitian studi literatur, dimana studi literatur adalah cara yang dipakai untuk menghimpun data atau sumber - sumber yang berhubungan dengan topik yang diangkat dalam suatu penelitian. Seperti jurnal dan buku yang terkait dalam perencanaan gempa dengan metode response spectrum. Buku acuan yang dipakai antara lain Tata cara Perencanaan Ketahanan Gempa untuk Struktur Bangunan Gedung dan Non Gedung SNI 1726 2012, Peraturan Beban Minimum untuk Perancangan Bangunan Gedung dan Stuktur lain SNI 1727 2013, tentang Tata Cara Perhitungan Struktur Beton untuk Bangunan Gedung, Peraturan Pembebanan Indonesia untuk Gedung 1983.

\subsection{Tahapan Penelitian}

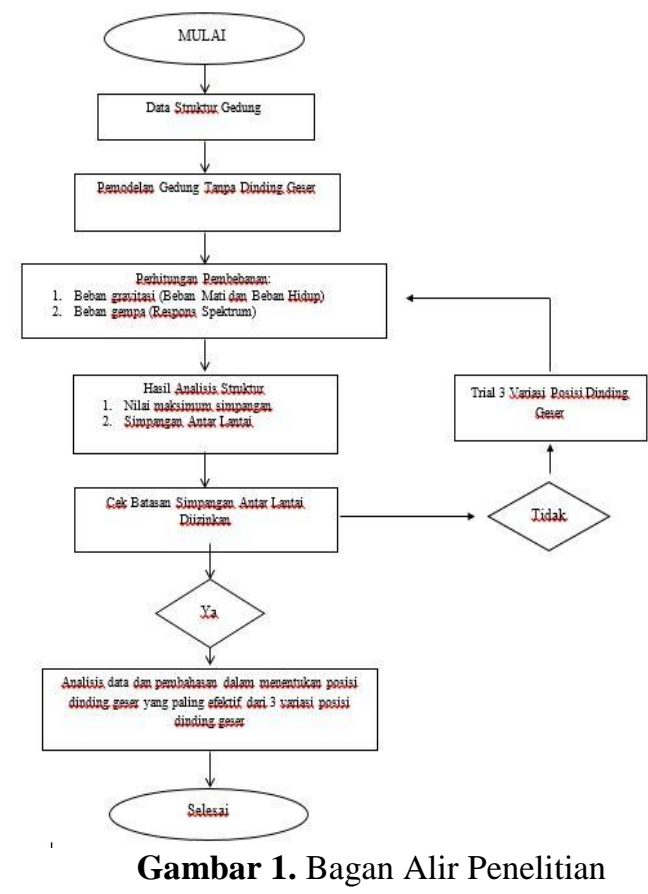

Penelitian dimulai dengan mengumpulkan data-data berupa data struktur, asumsi lokasi pemodelan gedung, fungsi gedung, jenis tanah yang digunakan, dan pembebanan. Data struktur gedung berupa denah, elemen struktur balok, kolom, plat lantai, dan dinding geser pada pemodelan gedung. Analisis pemodelan struktur gedung dengan menggunakan metode respons spektrum. Pembebanan mengacu pada SNI 1727-2013 untuk beban mati dan hidup SNI 1726-2012 untuk beban gempa. Setelah itu gedung dimodelkan dalam bentuk 3 dimensi dengan bantuan software ETABS. Model dibuat dalam bentuk gedung tanpa dinding geser dan 3 variasi

posisi gedung dengan dinding geser. Penentuan 3 variasi posisi dinding geser dilakukan dengan cara trial posisi dinding geser sehingga mendapatkan hasil kinerja simpangan struktur. Hasil kinerja simpangan struktur tersebut dihitung dan diperiksa yang berpedoman pada SNI 1726-2012. Terakhir melakukan pemilihan terhadap 3 variasi posisi dinding geser dan menentukan posisi yang paling efektif dalam menerima beban gempa.

\subsection{Data Struktur Gedung}

Untuk membuat pemodelan tiga dimensi gedung dalam penelitian ini maka dibutuhkan data-data dimensi keseluruhan dari komponen gedung. Pemodelan gedung tiga dimensi dapat dilihat pada Gambar 4.1. Data struktur gedung dapat dilihat pada Tabel 4.1.

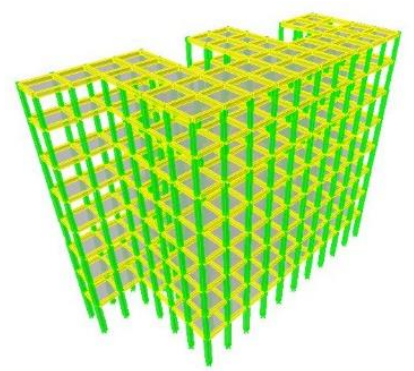

Gambar 2 Pemodelan Struktur Mengambil Contoh Gedung UIN Maliki Malang

Tabel 1 Data Struktur Gedung

\begin{tabular}{|c|l|l|}
\hline No & \multicolumn{1}{|c|}{ Kriteria } & \multicolumn{1}{c|}{ Studi Kasus } \\
\hline 1 & Sistem Struktur & Dual Sistem \\
\hline 2 & Fungsi Gedung & Pendidikan \\
\hline 3 & Jumlah Lantai & 8 Lantai \\
\hline 4 & Tinggi Lantai 1 & $6 \mathrm{~m}$ \\
\hline 5 & Tinggi Lantai 2-7 & $5 \mathrm{~m}$ \\
\hline 6 & Tinggi Lantai 8 & $4 \mathrm{~m}$ \\
\hline 7 & Tinggi Maksimum Gedung & $40 \mathrm{~m}$ \\
\hline 8 & Jenis Rangka & Beton Bertulang \\
\hline
\end{tabular}




\subsection{Data Konstruksi Gedung}

Dalam menganalisa data dan pembebanan struktur yang dipikul oleh struktur gedung bisa dilihat sebagai berikut:

1. Pembebanan untuk beban mati:
a. Berat isi beton : $2400 \mathrm{~kg} / \mathrm{m}^{3}$
b. Spesi per cm tebal: $2200 \mathrm{~kg} / \mathrm{m}^{2}$
c. Plafond + rangka: $18 \mathrm{~kg} / \mathrm{m}^{2}$
d. Pasangan $1 / 2$ bata: $250 \mathrm{~kg} / \mathrm{m}^{2}$

2. Pembebanan untuk Beban hidup:
a. Lantai Atap: $96 \mathrm{~kg} / \mathrm{m}^{2}$
b. Lantai ruang kuliah: $192 \mathrm{~kg} / \mathrm{m}^{2}$
c. Koridor : $383 \mathrm{~kg} / \mathrm{m}^{2}$

\subsection{Spesifikasi Material Struktur}

Pada penelitian ini spesifikasi material yang digunakan pada struktur gedung:

Kuat tekan beton fc' 25 (Balok dan plat lantai) dan Fc'30 (kolom dan dinding geser. Tegangan leleh baja $390 \mathrm{Mpa}$.

\section{HASIL DAN PEMBAHASAN}

\subsection{Variasi Denah Posisi Dinding Geser}

Berdasarkan hasil analisis pemodelan struktur gedung tanpa dinding geser dengan menggunakan metode respons spektrum berdasarkan parameter kinerja simpangan struktur. Dari hasil nilai kinerja simpangan struktur, maka struktur memerlukan dinding geser untuk menambah kekakuan pada struktur gedung tersebut. Maka dari itu didapat 3 variasi denah posisi dinding geser. 3 variasi denah posisi dinding geser dapat dilihat pada Gambar 3 sampai Gambar 6.

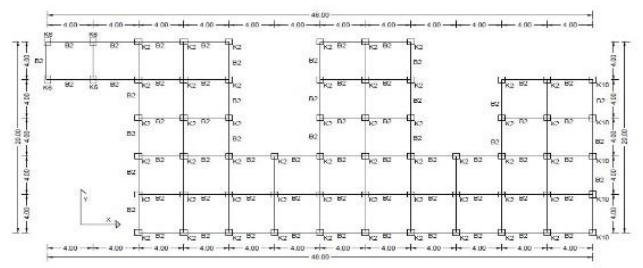

Gambar 3. Denah Tanpa Dinding Geser

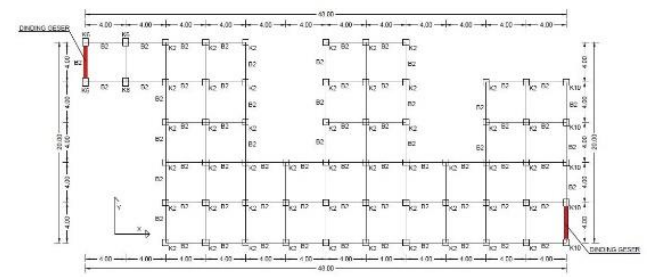

Gambar 4. Denah Posisi Dinding Geser Model 1

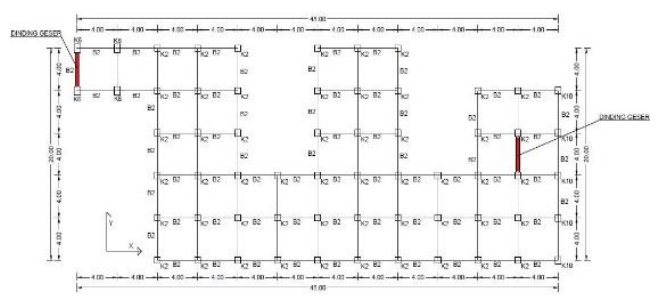

Gambar 5. Denah Posisi Dinding Geser Model 2

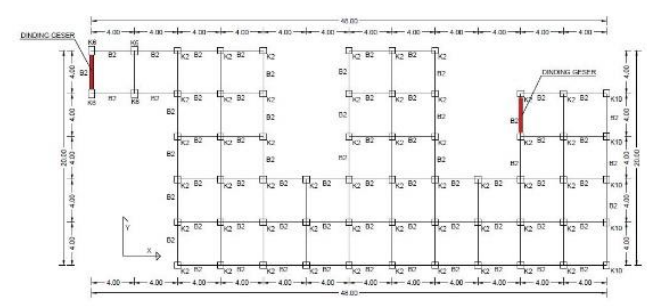

Gambar 6. Denah Posisi Dinding Geser Model 3

Pada Gambar 4 sampai dengan Gambar 6 semua model posisi dinding geser mengarah ke sumbu arah Y, itu dikarenakan pada posisi sumbu arah $\mathrm{Y}$ memiliki nilai simpangan maksimum lebih besar dari sumbu arah X.

\subsection{Hasil Tebal dan Volume Dinding Geser}

Berdasarkan hasil analisis dari gedung tanpa dinding geser, gedung dinding geser model 1, gedung dinding geser model 2, dan gedung dinding geser 3 didapat tebal dan Volume dinding geser yang digunakan pada pemodelan gedung dapat dilihat pada Tabel 2 dan Tabel 3.

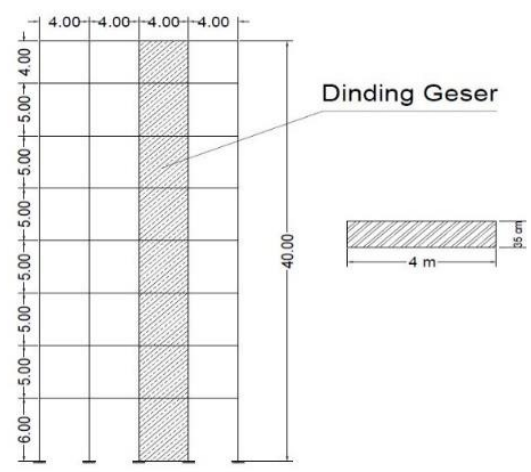


Pengaruh Posisi Dinding Geser Terhadap Kinerja Struktur (Sri Hartati Dewi)

Gambar 7 Tampak Dinding Geser

Tabel 2 Tebal Dinding Geser

\begin{tabular}{|l|c|c|}
\hline No & Jenis Struktur & Tebal Dinding Geser $(\mathrm{cm})$ \\
\hline 1 & Gedung dengan dinding geser model 1 & 35 \\
\hline 2 & Gedung dengan dinding geser model 2 & 35 \\
\hline 3 & Gedung dengan dinding geser model 3 & 35 \\
\hline
\end{tabular}

Sumber: Peshitungan

Tabel 3 Volume Dinding Geser

\begin{tabular}{|l|c|c|}
\hline No & Jenis Struktur & Volune Dinding Geser $\left(\mathrm{m}^{3}\right)$ \\
\hline 1 & Gedung dengan dinding geser model 1 & 112 \\
\hline 2 & Gedung dengan dinding geser model 2 & 112 \\
\hline 3 & Gedung dengan dinding geser model 3 & 112 \\
\hline
\end{tabular}

Sumber: Perhituggen

\subsection{Hasil Analisis Gempa Dengan Metode Respons Spektrum}

Berdasarkan hasil analisis struktur gedung dengan menggunakan metode respons spektrum pada pemodelan gedung tanpa dinding geser dan pemodelan gedung dengan dinding geser model 1, gedung dengan dinding geser model 2 , dan gedung dengan dinding geser model 3 yang menggunakan bantuan software ETABS diperoleh hasil story shear (gaya geser tingkat) dan Simpangan maksimum struktur akibat kombinasi pembebanan maksimum sesuai SNI 1726-2012.

\section{Hasil Nilai Story Shear (Gaya Geser Tingkat)}

Dari hasil analisis struktur yang dilakukan dengan bantuan software ETABS diperoleh story shear (gaya geser tingkat) akibat pembebanan

maksimum. Story shear dapat dilihat sebagai berikut:

a. Story shear pada gedung tanpa dinding geser

Tabel 3 Story Shear Pada Gedung TanpaDinding Geser

\begin{tabular}{|l|c|r|r|c|c|}
\hline \multicolumn{1}{|c|}{ Lantai } & Elevasi & $\mathrm{Fx}(\mathrm{KN})$ & $\mathrm{Fy}(\mathrm{KN})$ & $\mathrm{Vx}(\mathrm{KN})$ & $\mathrm{Vy}(\mathrm{KN})$ \\
\hline Lantai 8 & 40 & 1523.93 & 1420.21 & 1523.93 & 1420.21 \\
\hline Lantai 7 & 36 & 2118.41 & 2091.79 & 3642.34 & 3512 \\
\hline Lantai 6 & 31 & 1149 & 1299.7 & 4791.34 & 4811.7 \\
\hline Lantai 5 & 26 & 938.88 & 859.3 & 5730.22 & 5671 \\
\hline Lantai 4 & 21 & 807.02 & 753.37 & 6537.24 & 6424.37 \\
\hline Lantai 3 & 16 & 791.96 & 896.41 & 7329.2 & 7320.78 \\
\hline Lantai 2 & 11 & 885.15 & 883.8 & 8214.35 & 8204.58 \\
\hline Lantai 1 & 6 & 634.84 & 536.91 & 8849.19 & 8741.49 \\
\hline
\end{tabular}

b. Story shear pada gedung dengan dinding geser model 1

Tabel 4 Story Shear Pada Gedung Dinding Geser Model 1

\begin{tabular}{|c|c|c|c|c|c|}
\hline Lantai & Elevasi & $\mathrm{Fx}(\mathrm{KN})$ & $\mathrm{Fy}(\mathrm{KN})$ & $\mathrm{Vx}(\mathrm{KN})$ & $\mathrm{Vy}(\mathrm{KN})$ \\
\hline Lantai 8 & 40 & 1300.1 & 2074.59 & 1300.1 & 2074.59 \\
\hline Lantai 7 & 36 & 1691.29 & 2500.76 & 2991.39 & 4575.35 \\
\hline Lantai 6 & 31 & 974.67 & 1357.38 & 3966.06 & 5932.73 \\
\hline Lantai 5 & 26 & 758.38 & 1000.3 & 4724.44 & 6933.03 \\
\hline Lantai 4 & 21 & 654.11 & 997.29 & 5378.55 & 7930.32 \\
\hline Lantai 3 & 16 & 669.71 & 1091.89 & 6048.26 & 9022.21 \\
\hline Lantai 2 & 11 & 692.83 & 1142.16 & 6741.09 & 10164.4 \\
\hline Lantai 1 & 6 & 555.83 & 798.48 & 7296.92 & 10962.9 \\
\hline
\end{tabular}

c. Story shear pada gedung dengan dinding geser model 2

Tabel 5 Story Shear Pada Gedung Dinding Geser Model 2

\begin{tabular}{|c|c|c|c|c|c|}
\hline Lantai & Elerasi & $\mathrm{Fx}(\mathrm{KN})$ & $\mathrm{Fy}(\mathrm{KN})$ & $\mathrm{Vx}(\mathrm{KN})$ & $\mathrm{Vy}(\mathrm{KN})$ \\
\hline Lantai 8 & 40 & 1300.1 & 2074.59 & 1300.1 & 2074.59 \\
\hline Lantai 7 & 36 & 1691.29 & 2500.76 & 2991.39 & 4575.35 \\
\hline Lantai 6 & 31 & 974.67 & 1357.38 & 3966.06 & 5932.73 \\
\hline Lantai 5 & 26 & 758.38 & 1000.3 & 4724.44 & 6933.03 \\
\hline Lantai 4 & 21 & 654.11 & 997.29 & 5378.55 & 7930.32 \\
\hline Lantai 3 & 16 & 669.71 & 1091.89 & 6048.26 & 9022.21 \\
\hline Lantai 2 & 11 & 692.83 & 1142.16 & 6741.09 & 10164.4 \\
\hline Lantai 1 & 6 & 555.83 & 798.48 & 7296.92 & 10962.9 \\
\hline
\end{tabular}

d. Story shear pada gedung dengan dinding geser model 3

Tabel 6 Story Shear Pada Gedung Dinding Geser Model 3 


\begin{tabular}{|c|c|c|c|c|c|}
\hline Lantai & Elevasi & $\mathrm{Fx}(\mathrm{KN})$ & $\mathrm{Fy}(\mathrm{KN})$ & $\mathrm{Vx}(\mathrm{KN})$ & $\mathrm{Vy}(\mathrm{KN})$ \\
\hline Lantai 8 & 40 & 996.33 & 1564.01 & 996.33 & 1564.01 \\
\hline Lantai 7 & 36 & 1306.23 & 1924.6 & 2302.56 & 3488.61 \\
\hline Lantai 6 & 31 & 750.69 & 1096.12 & 3053.25 & 4584.73 \\
\hline Lantai 5 & 26 & 583.66 & 824.52 & 3636.91 & 5409.25 \\
\hline Lantai 4 & 21 & 502.17 & 789.03 & 4139.08 & 6198.28 \\
\hline Lantai 3 & 16 & 516.84 & 830.16 & 4655.92 & 7028.44 \\
\hline Lantai 2 & 11 & 532.62 & 847.87 & 5188.54 & 7876.31 \\
\hline Lantai 1 & 6 & 427.9 & 585.13 & 5616.44 & 8461.44 \\
\hline
\end{tabular}

\section{Hasil Analisis Kinerja Simpangan Maksimum Pada Struktur Gedung}

Berdasarkan hasil analisis struktur gedung dengan menggunakan metode respons spektrum pada pemodelan gedung tanpa dinding geser dan pemodelan gedung dengan dinding geser model 1, gedung dengan dinding geser model 2 , dan gedung dengan dinding geser model 3 yang menggunakan bantuan software ETABS diperoleh Simpangan maksimum struktur akibat kombinasi pembebanan maksimum sesuai SNI 1726-2012. Serta output nilai simpangan maksimum untuk arah sumbu $\mathrm{X}$ dapat dilihat pada Gambar 8

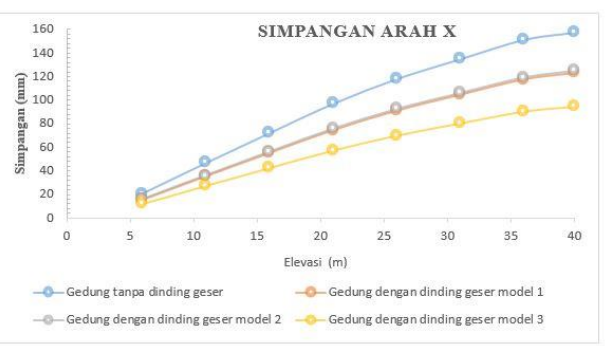

Gambar 8 Grafik Simpangan Maksimum Arah X

Berdasarkan data pada Gambar 8 didapat Simpangan maksimum struktur akibat kombinasi maksimum arah sumbu $\mathrm{X}$ pada gedung tanpa dinding geser sebesar $157,57 \mathrm{~mm}$, pada gedung dinding geser model 1 sebesar $123,41 \mathrm{~mm}$, pada gedung dinding geser model 2 sebesar 125,30 mm, pada gedung dinding geser model 3 sebesar $94,46 \mathrm{~mm}$. Berdasarkan nilai simpangan maksimum struktur tersebut pada arah sumbu $\mathrm{X}$ akibat beban kombinasi maksimum yang terkecil terdapat pada gedung dengan dinding geser model 3 .

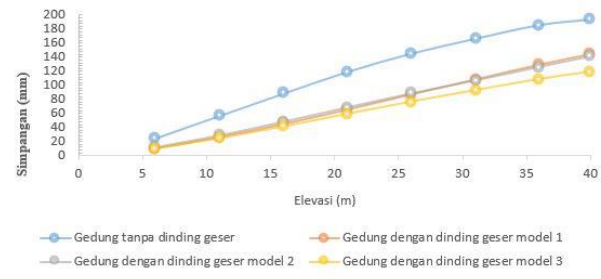

Gambar 8 Grafik Simpangan Maksimum Arah Y

Berdasarkan data pada Gambar 8 didapat Simpangan maksimum akibat kombinasi maksimum arah sumbu $\mathrm{Y}$ pada gedung tanpa dinding geser sebesar 193,13 mm, pada gedung dinding geser model 1 sebesar $143,79 \mathrm{~mm}$, pada gedung dinding geser model 2 sebesar 141,16 mm, pada gedung dinding geser model 3 sebesar 119,24 mm. Berdasarkan nilai simpangan maksimum struktur tersebut pada arah sumbu Y akibat beban kombinasi maksimum yang terkecil terdapat pada gedung dinding geser model 3.

\subsection{Hasil Analisis Kinerja Nilai Simpangan Antar Lantai Pada Gedung \\ Berdasarkan hasil analisis struktur} gedung dengan menggunakan metode respons spektrum pada pemodelan gedung tanpa dinding geser dan pemodelan gedung dengan dinding geser model 1, gedung dengan dinding geser model 2, dan gedung dengan dinding geser model 3. Dari hasil output simpangan maksimum yang didapat dari software ETABS, maka nilai simpangan antar lantai bisa dicari. Untuk memenuhi persyaratan kinerja struktur dalam hal simpangan antar lantai yang dihitung dari simpangan maksimum struktur gedung tidak boleh melebihi nilai $\Delta \mathrm{a}=(0,015) \times \mathrm{h}_{\mathrm{sx}} \quad\left(\right.$ tabel 3.17), $\mathrm{h}_{\mathrm{sx}}$ adalah tinggi lantai.

\section{Hasil Nilai Simpangan Antar Lantai Untuk Gedung Tanpa Dinding Geser}

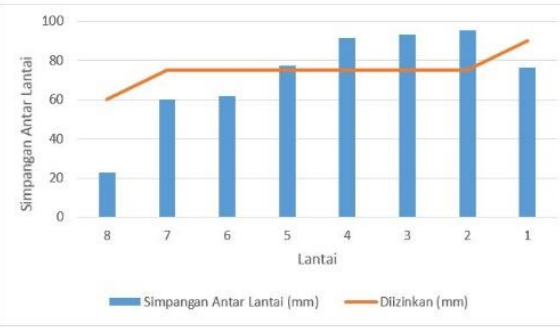


Gambar 9 Grafik Simpangan Antar Lantai Tanpa Dinding Geser Arah X

Berdasarkan data Gambar 9 menjelaskan bahwa untuk nilai simpangan antar lantai yang diizinkan atau nilai simpangan antar lantai tidak boleh melebihi nilai yaitu pada lantai 1 sebesar $90 \mathrm{~mm}$, untuk lantai 2 sampai 7 sebesar $75 \mathrm{~mm}$, dan untuk pada lantai 8 sebesar $60 \mathrm{~mm}$. Sedangkan nilai simpangan antar lantai pada sumbu arah $\mathrm{X}$ untuk gedung tanpa dinding geser adalah pada lantai 2, lantai 6 , lantai 7 dan lantai 8 sudah memenuhi nilai Batasan simpangan antar lantai yang dizinkan, dan pada lantai 2, lantai 3, lantai 4 dan lantai 5 belum memenuhi nilai Batasan simpangan antar lantai yang diizinkan berdasarkan SNI 1726-2012.

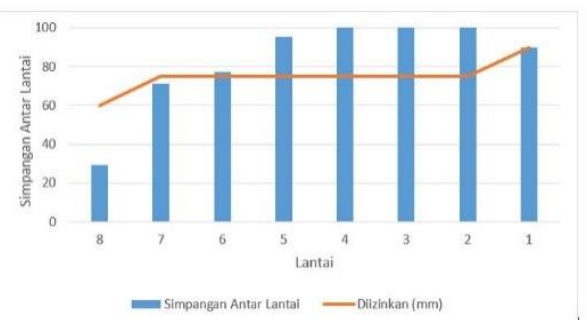

Gambar 10 Grafik Simpangan Antar Lantai Tanpa Dinding Geser Arah Y

Berdasarkan data Gambar 10 bahwa untuk nilai simpangan antar lantai yang diizinkan atau nilai simpangan antar lantai tidak boleh melebihi nilai yaitu pada lantai 1 sebesar $90 \mathrm{~mm}$, untuk lantai 2 sampai 7 sebesar 75 $\mathrm{mm}$, dan untuk pada lantai 8 sebesar 60 $\mathrm{mm}$. Sedangkan nilai simpangan antar lantai pada sumbu arah $\mathrm{Y}$ untuk gedung tanpa dinding geser adalah pada lantai 1 , lantai 7 dan lantai 8 sudah memenuhi nilai Batasan simpangan antar lantai yang dizinkan, dan pada lantai 2, lantai 3, lantai 4, lantai 5, dan lantai 6 belum memenuhi nilai Batasan simpangan antar lantai yang diizinkan berdasarkan SNI 1726-2012

\section{Hasil Nilai Simpangan Antar Lantai Untuk Gedung Dengan Dinding Geser Model 1}

Berdasarkan pada Gambar 11 menjelaskan bahwa untuk nilai simpangan antar lantai yang diizinkan atau nilai simpangan antar lantai tidak boleh melebihi nilai yaitu pada lantai 1 sebesar $90 \mathrm{~mm}$, untuk lantai 2 sampai 7 sebesar $75 \mathrm{~mm}$, dan untuk pada lantai 8 sebesar $60 \mathrm{~mm}$.

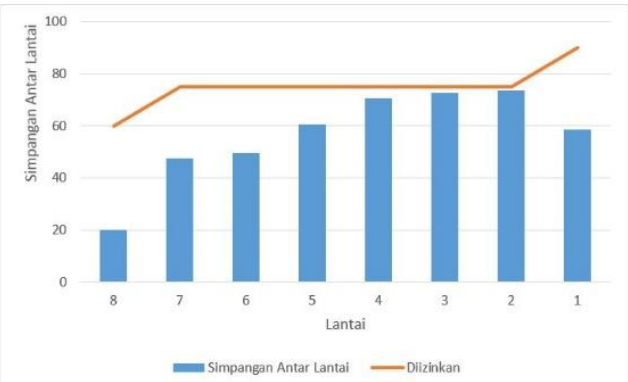

Gambar 11 Grafik Simpangan Antar Lantai Posisi Dinding Geser Model 1 Arah X

Untuk nilai simpangan antar lantai pada sumbu arah $\mathrm{X}$ untuk gedung dengan dinding geser model 1 pada semua lantai sudah memenuhi nilai Batasan simpangan antar lantai yang diizinkan berdasarkan SNI 1726-2012

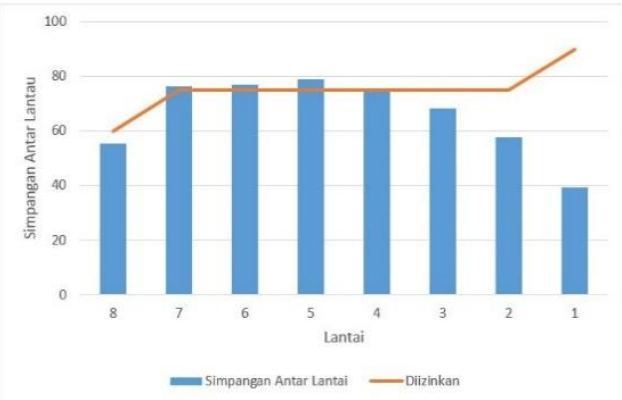

Gambar 12 Grafik Simpangan Antar Lantai Posisi Dinding Geser Model 1 Arah Y

Berdasarkan pada Gambar 12 menjelaskan bahwa untuk nilai simpangan antar lantai yang diizinkan atau nilai simpangan antar lantai tidak boleh melebihi nilai yaitu pada lantai 1 sebesar $90 \mathrm{~mm}$, untuk lantai 2 sampai 7 sebesar $75 \mathrm{~mm}$, dan untuk pada lantai 8 sebesar $60 \mathrm{~mm}$. Untuk nilai simpangan antar lantai pada sumbu arah $\mathrm{Y}$ untuk gedung dengan dinding geser model 1 adalah pada lantai 1, lantai 2, lantai 3, lantai 4 dan lantai 8 sudah memenuhi nilai Batasan simpangan antar lantai yang dizinkan, dan pada lantai 5, lantai 6, dan lantai 7 belum memenuhi nilai Batasan simpangan antar lantai yang diizinkan berdasarkan SNI 1726-2012.

\section{Hasil Nilai Simpangan Antar Lantai Untuk Gedung Dengan Dinding Geser Model 2}




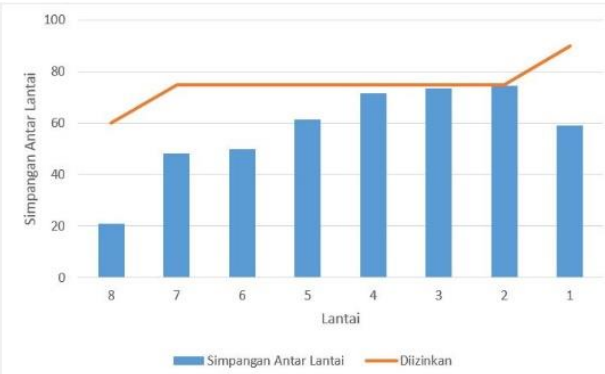

Gambar 13 Grafik Simpangan Antar Lantai Posisi Dinding Geser Model 2 Arah X

Berdasarkan pada Gambar 13 menjelaskan bahwa untuk nilai simpangan antar lantai yang diizinkan atau nilai simpangan antar lantai tidak boleh melebihi nilai yaitu pada lantai 1 sebesar $90 \mathrm{~mm}$, untuk lantai 2 sampai 7 sebesar $75 \mathrm{~mm}$, dan untuk pada lantai 8 sebesar $60 \mathrm{~mm}$. Untuk nilai simpangan antar lantai pada sumbu arah $\mathrm{X}$ untuk gedung dengan dinding geser model 2 pada semua lantai sudah memenuhi nilai Batasan simpangan antar lantai yang diizinkan berdasarkan SNI 1726-2012.

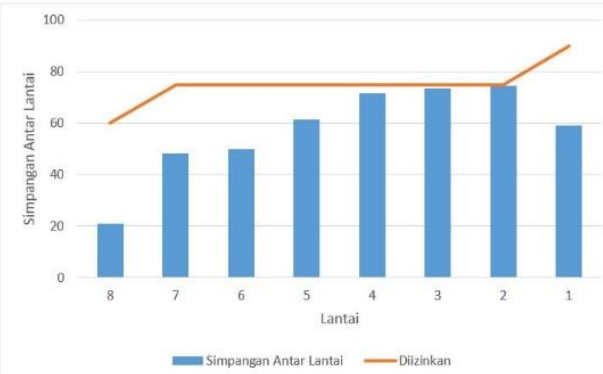

Gambar 14 Grafik Simpangan Antar Lantai Posisi Dinding Geser Model 2 Arah Y

Berdasarkan pada Gambar 14 menjelaskan bahwa untuk nilai simpangan antar lantai yang diizinkan atau nilai simpangan antar lantai tidak boleh melebihi nilai yaitu pada lantai 1 sebesar $90 \mathrm{~mm}$, untuk lantai 2 sampai 7 sebesar $75 \mathrm{~mm}$, dan untuk pada lantai 8 sebesar $60 \mathrm{~mm}$. Untuk nilai simpangan antar lantai pada sumbu arah Y untuk gedung dengan dinding geser model 2 adalah pada lantai 1, lantai 2, lantai 3, lantai 5, lantai 6, lantai 7 dan lantai 8 sudah memenuhi nilai Batasan simpangan antar lantai yang dizinkan, dan pada lantai 4 belum memenuhi nilai Batasan simpangan antar lantai yang diizinkan berdasarkan SNI 1726-2012

\section{Hasil Nilai Simpangan Antar Lantai Untuk Gedung Dengan Dinding Geser Model 3}

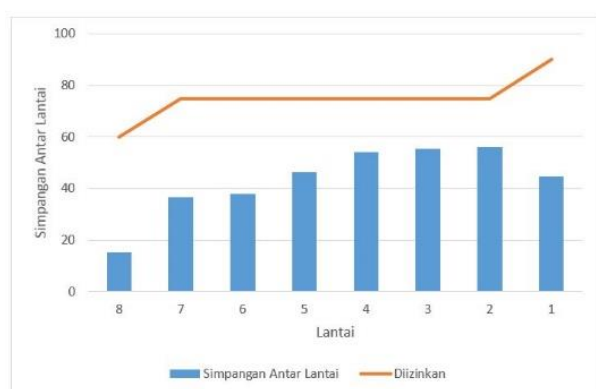

Gambar 15 Grafik Simpangan Antar Lantai Posisi Dinding Geser Model 3 Arah X

Berdasarkan pada Gambar 15 menjelaskan bahwa untuk nilai simpangan antar lantai yang diizinkan atau nilai simpangan antar lantai tidak boleh melebihi nilai yaitu pada lantai 1 sebesar $90 \mathrm{~mm}$, untuk lantai 2 sampai 7 sebesar $75 \mathrm{~mm}$, dan untuk pada lantai 8 sebesar $60 \mathrm{~mm}$. Untuk nilai simpangan antar lantai pada sumbu arah $\mathrm{X}$ untuk gedung dengan dinding geser model 3 pada semua lantai sudah memenuhi nilai Batasan simpangan antar lantai yang diizinkan berdasarkan SNI 1726-2012

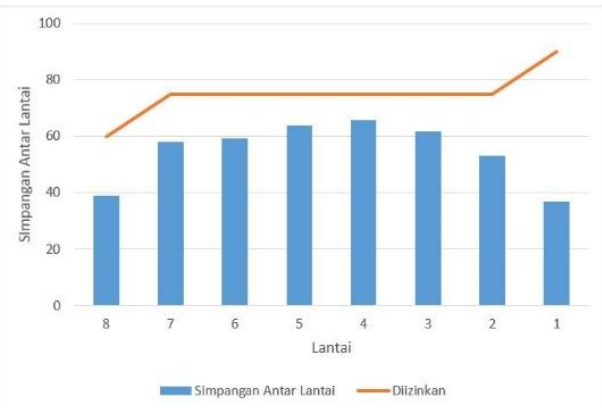

Gambar 16 Grafik Simpangan Antar Lantai Posisi Dinding Geser Model 3 Arah Y

Berdasarkan pada Gambar 16 menjelaskan bahwa untuk nilai simpangan antar lantai yang diizinkan atau nilai simpangan antar lantai tidak boleh melebihi nilai yaitu pada lantai 1 sebesar $90 \mathrm{~mm}$, untuk lantai 2 sampai 7 sebesar $75 \mathrm{~mm}$, dan untuk pada lantai 8 sebesar $60 \mathrm{~mm}$. Untuk nilai simpangan antar lantai pada sumbu arah Y untuk gedung dengan dinding geser model 3 pada semua lantai sudah memenuhi nilai Batasan simpangan antar lantai yang diizinkan berdasarkan SNI 1726-2012 


\section{KESIMPULAN DAN SARAN \\ 4.1 Kesimpulan}

Berdasarkan hasil analisa data dan pembahasan dalam penelitian ini, maka dapat diambil kesimpulan sebagai berikut :

1. Dari hasil perhitungan pada Gedung tidak beraturan dengan metode respons spektrum didapat hasil untuk kinerja simpangan antar lantai yang ditinjau berdasarkan SNI 1726: 2012 adalah sebagai berikut:

a. Gedung tanpa dinding geser untuk arah X pada lantai 2, lantai 3, lantai 4 dan lantai 5 melebihi batas nilai yang simpangan lantai diizinkan sebesar 75 $\mathrm{mm}$. Sedangkan untuk arah Y pada lantai 2, lantai 3, lantai 4, lantai 5 dan lantai 6 juga melebihi batas nilai yang simpangan lantai diizinkan sebesar 75 $\mathrm{mm}$.

b. Gedung dengan dinding geser model 1 untuk arah $\mathrm{X}$ pada semua lantai telah memenuhi batasan yang dizinkan. Sedangkan untuk arah Y pada lantai 5, lantai 6 dan lantai 7 melebihi batas nilai yang simpangan lantai diizinkan sebesar $75 \mathrm{~mm}$.

c. Gedung dengan dinding geser model 2 untuk arah $\mathrm{X}$ pada semua lantai telah memenuhi batasan yang dizinkan. Sedangkan untuk arah Y pada lantai 4 melebihi batas nilai yang simpangan lantai diizinkan sebesar $75 \mathrm{~mm}$.

d. Gedung dengan dinding geser model 3 untuk arah $\mathrm{X}$ dan arah $\mathrm{Y}$ pada semua lantai telah memenuhi batasan yang diizinkan berdasarkan SNI 1726-2012.

2. Dari hasil kinerja simpangan antar lantai pada gedung tidak beraturan dengan metode respons spektrum didapat posisi dinding geser yang paling efektif adalah pada Gedung dengan dinding geser model 3.

\subsection{Saran}

Adapun saran - saran yang dapat disampaikan berdasarkan penelitian yang telah dilakukan ini agar penelitian - penelitian selanjutnya lebih baik adalah sebagai berikut :

1. untuk penelitian selanjutnya dapat dicoba melakukan analisa gempa menggunakan metode time history dan metode analisis non linier untuk mengetahui letak sendi plastis sehingga pola keruntuhan bisa diketahui.

\section{DAFTAR PUSTAKA}

Adhitama, Azmi, 2016. Analisis Kinerja Gedung Bbertingkat Berdasarkan Eksentrisitas Layout Dinding Geser Terhadap Pusat Massa Dengan Metode Pushover. Tugas Akhir, Jurusan Teknik Sipil Fakultas Teknik Universitas Sebelas Maret.

Bambang, Budiono, 2011. Konsep SNI Gempa 1726-201x. Makalah dalam Seminar HAKI.

Budiono, Bambang., dan Supriatna, Lucky., 2011.Studi Komparasi Desain

Bangunan Tahan Gempa Dengan Menggunakan SNI 03-1726-2002 dan RSNI 03-1726-201X. Bandung: Penerbit ITB.

Departemen Pekerjaan Umum, 1987. Pedoman Perencanaan Pembebanan Untuk Rumah Dan Gedung. PPPURG. Jakarta.

Departemen Pekerjaan Umum, 2012. Tata Cara Perencanaan Ketahanan Gempa Untuk Struktur Bangunan Gedung. Jakarta.

Departemen Pekerjaan Umum, 2013. Persyaratan Beton Struktural Untuk Bangunan. Jakarta.

Departemen Pekerjaan Umum, 2013. Beban Minimum Untuk Perencanaan Bangunan Gedung Dan Struktur Lain SNI 03 - 1727 - 2013. Jakarta.

Nurcahyo, Heru, 2016, Kajian Posisi Shear Wall Pada Gedung Tidak Beraturan Berdasarkan Eksentrisitas Struktur Gedung. Tugas Akhir, Program Studi Teknik Sipil Fakultas Teknik Universitas Riau. 
Rendra, Rezky, 2015, Analisis Kinerja Struktur Akibat Beban Gempa Dengan

Metode Respon Spektrum dan Time

History. Tugas Akhir, Program Studi

Teknik Sipil Fakultas Teknik

Universitas Riau.

Schueller, Wolfgang, 1989, "Struktur

Bangunan Bertingkat Tinggi, PT.

Bresco, Bandung.

Wight, J. K., and MacGregor, J. G., 2012.

Reinforced Concrete Mechaics \&

Design. United States of America:

Pearson Education, Inc.

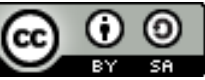

This is an open access article which means that all content is freely available without charge to the user or his/her institution. Jurnal Saintis allows the author(s) to hold the copyright without restriction. The copyright in the text of individual articles (including research articles, opinion articles, and abstracts) is the property of their respective authors distributed under the terms of the Creative Commons Attribution-ShareAlike 4.0 International License(https://creativecommons.org/licenses/by-sa/4.0/) which permits unrestricted use, distribution, and reproduction in any medium. Users are allowed to read, download, copy, distribute, search, or link to full-text articles in this journal without asking by giving appropriate credit, provide a link to the license, and indicate if changes were made. 